\title{
Comparison the Psychological Wellbeing of University Students from Hungary and Romania
}

\author{
Anita BARTH, Ildikó NAGY, János KISS \\ barthanita@hotmail.com, ildinagy1o@gmail.com, \\ kiss.janos@foh.unideb.hu \\ (University of Debrecen, Debrecen, Hungary)
}

Received: 08.01.2015; Accepted: 04.21.2015

\begin{abstract}
The results obtained in our research of mental distress indicators and results of conflict management strategies are consistent with the results of international studies. Students participating in the study $(N=237)$ reached the highest average results in the field of personal growth, while we measured the lowest value in the fields of autonomy and the dominance of the enviroment. Among the mental distress indicators the students gave the highest scores for the stress. The frequency examination showed the results of the participants to fall to 40.9\% of moderate-severe and severe extreme range. While among the genders, women indicate much higher stress levels. In addition, the students preferred the avoiding conflict management strategy in preference to the other four strategies. While we compared the students from the two countries we found a significant difference between the survey field of autonomy and purpose in life. We also found a notable difference among the mental distress indicators. While the students of the University of Debrecen were moderate, the students of the universities of Oradea fell in the "slight" area (in the range of stress). For the usage of conflict management strategies we found no significant differences between the two countries' students. The students from both countries preferred the avoiding strategy. This study similiar to many national and international studies indicates the high level of stress among the students. One of the most important task of a higher education institution should be the protection of the students' mental health which would lead to an improvement on well-being and that would cause the lowering of the stress level.
\end{abstract}

Keywords: comparative study, stress and distress, wellbeing, psychology 
During our research, we were studying the psychological wellbeing as well as the influence of negative emotional states and conflicts of young people in the higher education systems and these interrelations were analysed in the two country's higher education institutions.

In the topic choice it played a role that nowadays the stress level of youth students in universities is becoming an ever more important issue and how this is affecting their mental and somatic state.

Gradually appeared the need, that the social environments, such as universities should ensure a happy and satisfactory life. The current educational institutions are rather the source of fear and stress than a scene of happy life.

Young students who are entering into the higher education system are forced to face numerous challenges. First of all, they have to fit into a new environment and they need to learn the course of study administration, then they must experience the difficulty of living independent in dorm or in a rented flat. It can affect disconcertingly the stressful situations in exams, the tight deadlines, the need of satisfaction in certain requirements and the everyday conflicts. Overwhelming feeling, but it can be also a good challenge to meet the requirements of the parents or the teachers. Not everybody can handle these stressful situations appropriately and without proper counselling it can affect negatively the student's wellbeing even it can lead several physical and mental illnesses (Kopp, 2003; Császár, 1980). Many studies support the idea (Hazag \& Major, 2008; Móczár, 2012), that nowadays the number of students studying in higher education having some kind of mental or psychosomatic illness are increasing. In spite of this problem the solution is still missing. Although there are some minor attempts in the form of various mental health programs, but those who would need the most, they don't get the chance getting some of these programs. We assume that one of the reasons is that the students are not informed in an appropriate manner (or not at all) about their opportunities.

Our aim is a more accurate characterization and identification of students with mental health factors, which could help to improve mental health in the context of higher education. With the results of this study we would like to contribute to the efficiency of primary prevention programs and to help the professionals working with young students. On the other hand, we would like to broaden the validation of databases Ryff-18 and DASS-21. The DASS21 questionnaire validation is made by Karolina Kósa and Katalin Tolvay (University of Debrecen, Faculty of Public Health, Department of Behavioural Sciences). The Ryff questionnaire is translated by Éva Kállay and László Csaba Dégi (Babes Bólyai University of Cluj), and the validaiton process is made by a joint research group in Hungary whose members are: Éva Kállay, László Csaba Dégi, Judit Sass, Éva Bodnár, János Kiss. 


\section{Research methods}

\section{Introduction of the sample - a few word about the examined universities}

The research was conducted at the University of Debrecen, the Partium Christian University and the State University of Oradea among students.

The University of Debrecen, Hungary's oldest institution of higher learning started its operations in 1914 with 3 faculty which later expanded into 15 faculty(Faculty of Law, Faculty of Medicine, Faculty of Arts \& Humanities, Faculty of Health, Faculty of Dental Medicine, Faculty of Economic Sciences, Faculty of Child and Adult Education, Faculty of Pharmacy, Faculty of Informatics, Faculty of Environmental ManagementAgriculture and Food Sciences, Faculty of Engineering, Faculty of Public Health, Faculty of Science and Technology, Faculty of Music). The courses can be chosen in Hungarian and English (1).

The State University of Oradea also has a great history, because it is one of the oldest institution in Eastern Europe. Currently, there are 15 faculties in it, similar to the University of Debrecen. The courses can be chosen in Romanian, English and Hungarian (2).

The Partium Christian University became independent and accredited in 2008, which main goal is to continue the tradtion of the Transylvanian education in Hungarian language. The main aim of the university is to provide equal opportunities in education in Transylvania and in the Partium and train competitive proffessionals. Currently, the university functions with 3 faculties (Faculty of Arts \& Humanities, Faculty of Economic Sciences, Faculty of Arts) (3).

\section{The sampling}

The selection was made using a simple random sample method. The survey was concluded in the second semester of the year 2013/14, it was self-administered and completed via the Internet using a questionnaire. Therefore, we decided in the electronic data collection, because the Internet plays an essential role in the lives of the population. The questionnaire was filled out with students in active legal relationship. The total sample was 237 people: 147 persons from the University of Debrecen, while 90 people in two University of Oradea.

\section{Presentation of the measuring instruments used}

Research methodology as the standard questionnaire study was chosen because a significant number of elements can be done this way. We believe that the psychological well-being and the factors affecting it can be best explored via self-administered questionnaires. A questionnaire consisting of 76 elements can be divided into four groups based on the question part. The respondents answering the first seven question answered the basic socio-demographic datas such as gender, age, which university they are 
attending, specialization, school year, work schedule and the level of education.

This was followed by the DASS (Depression Anxiety and Stress Scale) questionnaire, which measures three negative emotional states: depression, anxiety and stress. The self-administered questionnaire is based on the Likert-scale. The Likert - scale ticked categories are: from 0 to 3, where (o) was not at all typical of me and (3) It is a very common characteristic of me (Henry \& Crawford, 2005).

The third part contained the Ryff Well-Being Scale. In the questionnaire, the allegations are relating to six factor (autonomy, environmental mastery, personal growth, positive relations with others, purpose in life, and self-acceptance). Each factors include three questions. The answers can be given in a six-pointed Likert-scale and they show how typical are the properties for the given person based on his/her answer. The assignable categories in the Likert-scale are: from o to 6, where the (1) is I do not agree; while (6) is I strongly agree (Ryff, 1989).

The final part of the questionnaire was developed by Kenneth W. Thomas and Ralph H. Kilmann with the aim of examining the individual behavior in conflict situations. The questionnaire consists of 30 pairs statement which gives a score for all five conflict management strategy (competiting, collaborating, compromising, avoiding, accommodating). This score indicates that how often we chose a particular behavior pattern. The result shows the useage frequency of the conflict management methods (Thomas \& Kilmann, 1974).

The questionnaire was completed in electronic form which took about 10-15 minutes.

The processing and analysis was performed by a mathematicalstatistical method using SPSS (Statistical Package for Social Science) software. In the analysis we carried out the following steps: average calculation, dispersion, frequency, two-sample (independent samples) ttest, Mann-Whitney test, confidence interval, correlation.

\section{Results}

\section{The socio-demographic characteristics of the students}

The study was completed 237 questionnaires. We didn't met with a questionnaire, which would have been totally inappropriate for evaluation. We only found an evaluable answer in one issue group („School Year”; 11 pieces, $4.65 \%)$.

Because we got back fewer questionnaires from the two universites of Oradea than we expected, that is why we treated the students of the two universities as one group $(\mathrm{N}=90)$. We believe the merging can be done for two reasons. First of all, the questionnaires were available only in Hungarian, so we were assumed that those members of the population have been completed in Oradea, who understand and speak Hungarian language. Secondly, both of the universities are located in Oradea.

Thus, the total sample, $62 \%$ (147 people), University of Debrecen, while $38 \%$ comes from two Oradea University. 
Among the participants, $73 \%$ (174 people) female and $27 \%$ (63 people) are men. The respondents' average age is 22 years. The youngest respondent was 18 and the oldest was 46 years old. Among the participants we examined the distribution according to the learned specializations. Those who are learning a helping profession makes the $65 \%$ of the total. This means that most of them are general practitioner, nurse, paramedic, midwife, health care organizer, psychology and social work student.

\section{Psychological well-being in higher education}

The psychological well-being of the participants is shown on Figure 1.

\section{Figure 1}

The average of psychological well-being among the students

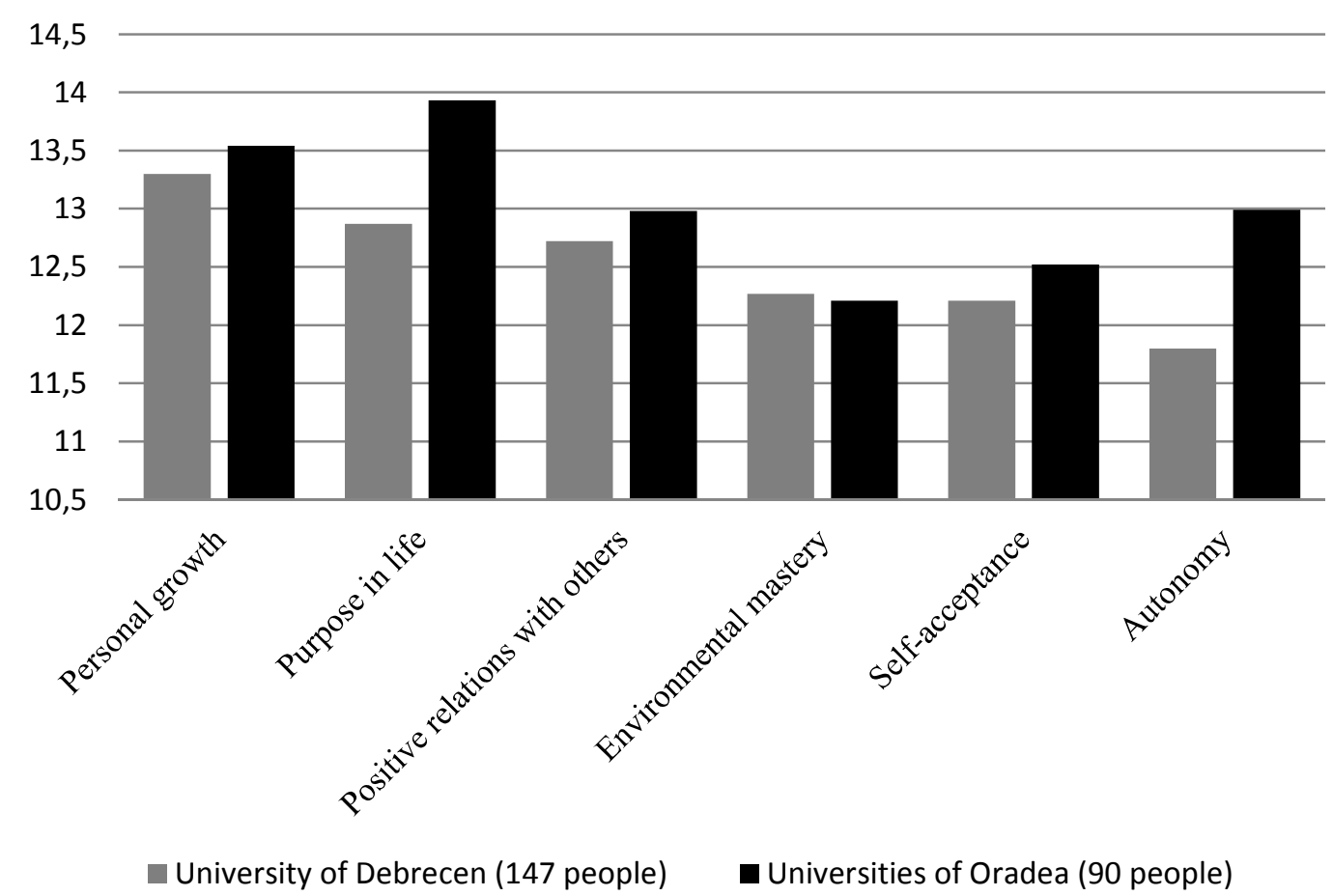

Personal growth. Based on the measured average results, we can say that there is only minimal difference between the University of Debrecen (average: 13.3) and the two universities of Oradea (average: 13.54). So, it can't be said that the students of the University of Debrecen are more able to re-open for self-realization than the students of the two universities in Oradea.

Purpose in life. There are large differences in the area of the life goals. The average score of life goal among the students of the University of Debrecen is 12.87, while the average score in the two Oradean universities are 13.93. After we conducted the t-probe test (independent sampled) we got the result that there is a significant differance between the results of the students $(p=0.018)$. From this it can be concluded that the students 
from the two universities of Oradea have stronger ideas about their goals and they believe the sence of their life in the present and in the past.

Positive relations with others. Based on the positive relationships with others dimension measured average results we can say that there is only minimal difference between the University of Debrecen (average: 12.72) and the two universities of Oradea (average: 12.98). So, it can't be said that the students of the University of Debrecen are more empathic, honest with others than the students of the two universities in Oradea.

Self-acceptance. Based on the self-acceptance dimension measured average results we can say that there is only minimal difference between the University of Debrecen (average: 12.21) and the two universities of Oradea (average: 12.52). So, it can't be said that the students of the University of Debrecen have a more positive self-image than the students of the two universities in Oradea.

Autonomy. There are large differences in the area of autonomy. The average score of autonomy among the students of the University of Debrecen is 11.8, while the average score in the two Oradean universities are 12.99. Based on the results of the t-probe test we can say that the difference is significant. So, the students in the universities of Oradea are self-evaluating their own standard and they are staying independent even in a social pressure.

Environmental mastery. Based on dominance of the enviroment dimension measured average results we can say that there is only minimal difference between the University of Debrecen (average: 12.27) and the two universities of Oradea (average: 12.21).

\section{The students mental distress indicators}

Figure 2

\section{The students mental distress indicators}

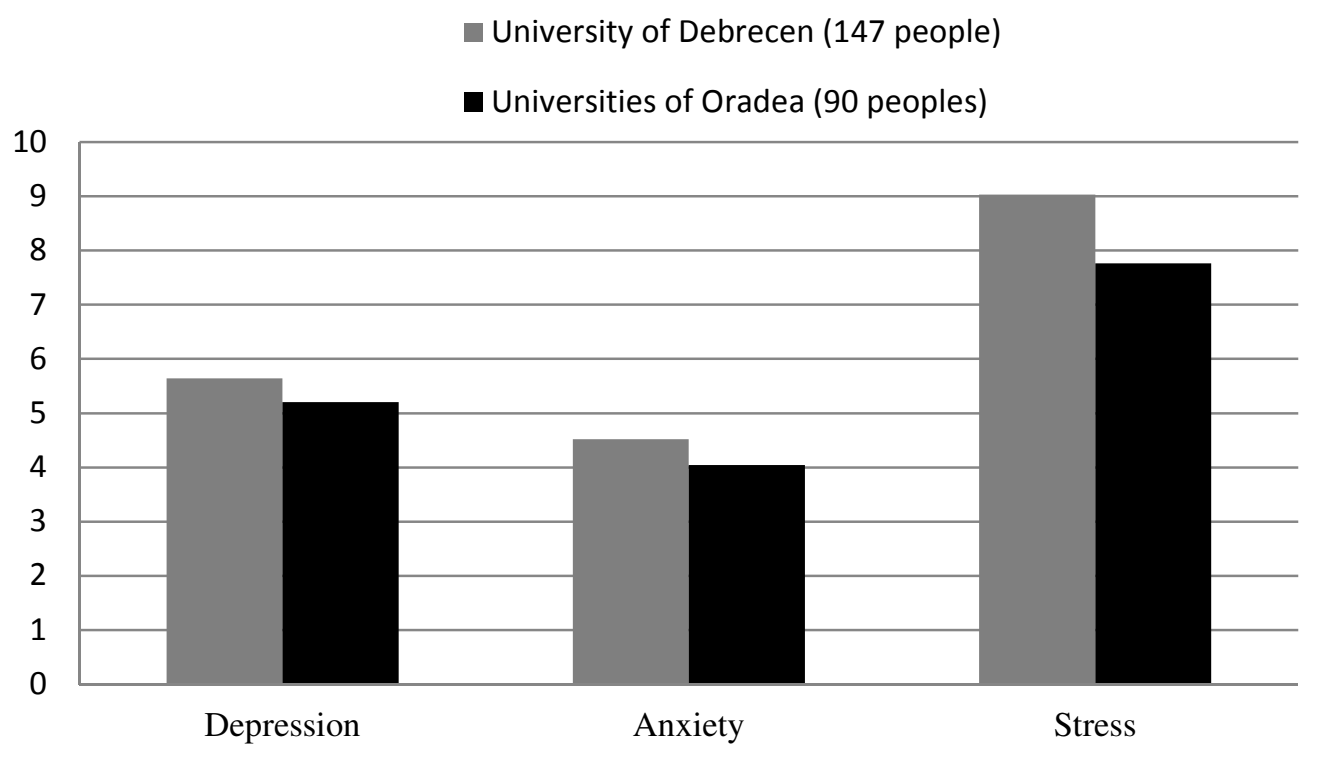


Depression. On this scale, the students of Debrecen reached a higher score, but the difference between the two are very little. (average: 5.64 > 5.2).

Anxiety. The anxiety scale of the Debrecen University students also achieved a higher score, but the difference were minimal here, too (average: $4.52>4.04$ ). So it can't be said that the students from Debrecen are more anxious than the students from Oradea.

Stress. Significant differences were measured on the scale of stress. The average score among the students from Debrecen is 9.03, while the average of the Oradean students are 7.76. Based ont he result of the parametric $\mathrm{t}$-probe test $(\mathrm{p}=0.042)$, we can say that there is a significant difference among the two average values. So, the students of the University of Debrecen are more stressful than the students in the other side of the border. We believe this is due to the specialization. Among the students of Debrecen, there are much more individual who chose a helping profession for themselves. Furthermore, among the students of the two universities of Oradea there are 53 people who are attending to the university with Christian life-values. A number of studies have demonstrated that the religion offers peace of mind and a positive effect on health (Indries, 2005). In addition, from the two Romanian universities there were only 90 survey-participants, while from Debrecen were 147 students who completed the task. The unequal distribution is also can cause different results. However, the students of the universities of Oradea having lower stress levels may also indicate, that in spite of they are living in minority they still have the chance to keep their identity (Tóth, 1991).

\section{Results related to conflict management strategies}

\section{Figure 3 \\ Average of conflict management strategies used by students}

- University of Debrecen Universities of Oradea

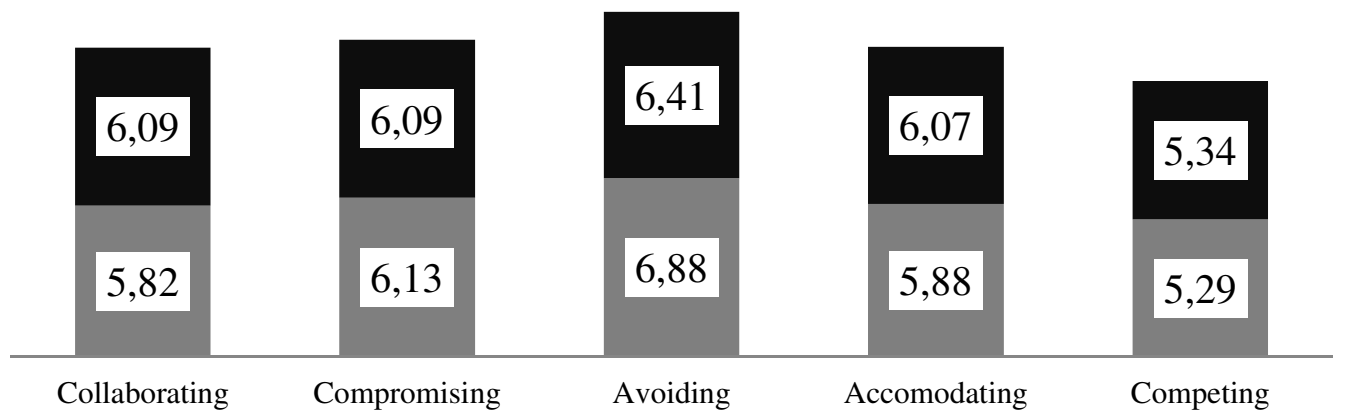

The figure shows that there are minimal differences between the average scores of the students. The highest score we got is for the avoiding, while the lowest was the competing conflict management strategy among students in both countries. This means that students usually have low assertiveness and cooperation skills. The majority of the students are avoiding the conflicts so that they can achieve their own aim, however they 
don't cooperate with the other to reach their goal, so it is a lose-lose situation. Considering the $95 \%$ confidence level it can be said that while among the students of the University of Debrecen the conflict management strategy's minimum (average: 6.49 ) and maximum (average: 7.27 ) are not overlapping with other conflict management strategy's of minimum and maximum average, so it is completely separate from the others, while it is can't be said among the students from the universities of Oradea.

\section{References}

Császár Gy. (1980). Pszichoszomatikus orvoslás. Budapest: Medicina.

Hazag A., \& Major J. (2008). A hallgatói kiégés jelensége, medikusok lelki egészségvédelme. Mentálhigiéné és Pszichoszomatika, 9 (4), 305-322. Indries K. (2005). Vallásosság. [Kutatási jelentés]. Budapest: Országos Epidemiológiai Központ.

Kopp M. (2003). Mikor káros a stressz? A stressz szerepe az egészségromlásban. Hippocrates, 5 (1), 44-48.

Móczár Á. (2012). Gyógypedagógus hallgatók társas támogatásának vizsgálata. [Thesis.] Budapest: ELTE-BGGYK.

Ryff, C. (1989). Happiness is everything, or is it? Explorations on the meaning of psychological well-being. Journal of Personality and Social Psychology, 57 (6), 1069-1081.

Thomas, K. W., \& Kilmann, R. H. (1974). Thomas-Kilmann conflict mode instrument. New York: Xicom.

Tóth P. P. (1991). Kreativitás és stressz a kisebbségben élő magyarság körében. Regio, 2 (2), 156-166. 